Boston University School of Law

Scholarly Commons at Boston University School of Law

Faculty Scholarship

2003

The Right to Health and the Nevirapine Case in South Africa

George J. Annas

Follow this and additional works at: https://scholarship.law.bu.edu/faculty_scholarship

Part of the Health Law and Policy Commons 


\title{
The Right to Health and the Nevirapine Case in South Africa
}

\author{
George J. Annas, J.D., M.P.H.
}

Thanks to activists in South Africa, the right to health as a human right has returned to the international stage, just as it was being displaced by economists who see health through the prism of a globalized economy and by politicians who see it as an issue of national security or charity. The current post-apartheid debate in South Africa is not about race but about health, and in this context, the court victory by AIDS activists in the nevirapine case has been termed not only, as stated in one British newspaper, "the greatest defeat for [President Thabo] Mbeki's government" but also the opening of "legitimate criticism" of the government "over a host of issues from land rights to the pursuit of wealth."1 Using the nevirapine case as a centerpiece, I will explore the power of the human right to health in improving health generally.

Jonathan Mann rightly observed that "health and human rights are inextricably linked,"2 and Paul Farmer has argued that "the most important question facing modern medicine involves human rights."3 Farmer noted that many poor people have no access to modern medicine and concluded, "The more effective the treatment, the greater the injustice meted out to those who do not have access to care." 3 Access to treatment for infection with the human immunodeficiency virus (HIV) and AIDS has been problematic in most countries, but especially in South Africa, where almost 5 million people are infected with HIV and the government's attitude toward the epidemic has been described as pseudoscientific and dangerous. ${ }^{4}$ Political resistance by the South African government to outside funders who want to set the country's health care agenda is, of course, understandable in the context of racism and colonialism. ${ }^{5}$ But even understandable politics cannot excuse the government's failure to act more decisively in the face of an unprecedented epidemic.

\begin{tabular}{c} 
HIV INFECTION \\
AND THE RIGHT TO HEALTH \\
\hline
\end{tabular}

One of the most controversial actions of the South African government was its restriction of the use of nevirapine to prevent the transmission of HIV from mothers to infants. Only two government hospitals per province were allowed to use the drug. The Treatment Action Campaign was formed in 1998 as a coalition of South African AIDS-related organizations to promote affordable treatment for all people with HIV infection or AIDS. This group (and others) scored a victory in 2001, when 39 multinational pharmaceutical companies withdrew their lawsuit against the South African government, which sought to enforce their patents on drugs for the treatment of HIV infection or AIDS, in order to prevent the government from purchasing generic versions of the drugs. ${ }^{6}$

At about the same time, the Treatment Action Campaign brought a suit against the South African government itself, alleging that its restrictions on the availability of nevirapine (limiting it in the public sector to hospitals involved in a pilot study) and its failure to have a reasonable plan to make the drug more widely available violated the right to health of HIV-positive pregnant women and their children guaranteed in the South African constitution. The use of nevirapine remains controversial in Africa, even after a study in Uganda, published in 1999, suggested that administering the drug to a pregnant woman at the onset of labor and to her newborn immediately after birth could result in a 50 percent reduction in the rate of transmission of HIV. ${ }^{7}$ This is the basis for the claim that failure to use nevirapine condemns 35,000 newborns a year to HIV infection in South Africa. ${ }^{1}$

The Treatment Action Campaign prevailed in the trial court, which ruled that restricting nevirapine to a limited number of pilot sites in the public 
sector "is not reasonable and is an unjustifiable barrier to the progressive realization of the right to health care." 8 In July 2002, the Constitutional Court of South Africa, the country's highest court, affirmed the ruling, stating that the government's nevirapine policy violated the health care rights of women and newborns under the South African constitution. ${ }^{9}$ Section 27 of the post-apartheid constitution states, "(1) Everyone has the right to have access to (a) health care services, including reproductive health care; (b) sufficient food and water; and (c) social security. . . . (2) The state must take reasonable legislative and other measures, within its available resources, to achieve the progressive realization of each of these rights. (3) No one may be refused emergency medical treatment." Section 28 states, "(1) Every child has a right . . . (b) to family care or parental care, or to appropriate alternative care when removed from the family environment; (c) to basic nutrition, shelter, basic health care services and social services. . . . (2) A child's best interests are of paramount importance in every matter concerning the child." 9

These rights are part of the bill of rights in the South African constitution, which the constitution itself requires the state to "respect, protect, promote and fulfill." These provisions are modeled on those in the International Covenant on Economic, Social and Cultural Rights (which has been signed, but not yet ratified, by South Africa). ${ }^{10}$ Under the covenant, the right to health includes not only appropriate health care, but also the underlying determinants of health, including clean water, adequate sanitation, safe food and housing, and health-related education. ${ }^{11}$ South Africa's constitutional health obligations apply to every branch of government. The Constitutional Court considered two questions: what actions the government was constitutionally required to take with regard to nevirapine, and whether the government had an obligation to establish a comprehensive plan for the prevention of HIV transmission from mother to child.

MAKING NEVIRAPINE AVAILABLE

As justification for its refusal to make nevirapine generally available in public clinics, the South African government has argued that the drug's safety and efficacy have not been satisfactorily established and that it is of limited benefit in a breast-feeding population (since the number of infants acquiring HIV from breast-feeding would be almost as large as the number infected in the absence of preventive treatment with nevirapine). These views have been articulated by the minister of health, who along with President Mbeki, continues to take positions on HIV infection and its treatment that scientists in the rest of the world find baffling. 4,5

In January 2001, after a meeting of southern African countries, the World Health Organization recommended the administration of nevirapine to HIV-positive women who are pregnant and to their children at the time of birth. In April 2001, the Medicines Control Council, South Africa's equivalent of the Food and Drug Administration, formally approved nevirapine as safe and effective. Shortly thereafter, in July 2001, the government decided to do the pilot study of nevirapine that was at issue in the lawsuit; this study limited the drug's availability to two sites in each province. The result was that physicians who worked at other facilities in the public sector were unable to prescribe this drug for their patients, even though the manufacturer of the drug, Boehringer Ingelheim, had agreed to make it available at no cost for a five-year period.

The Treatment Action Campaign argued that in the face of the HIV epidemic, which includes the infection of approximately 70,000 infants from their mothers annually, it was irrational and a breach of the bill of rights for the government to prohibit physicians in public clinics from prescribing nevirapine for preventive purposes when medically indicated. 9

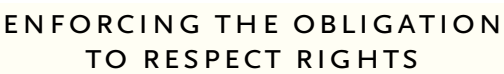

This was the third case in which the Constitutional Court had been asked to enforce a socioeconomic right under the South African constitution. The first, Soobramoney v. Minister of Health, was also a right-tohealth case. ${ }^{12}$ It involved a 41 -year-old man with chronic renal failure and a history of stroke, heart disease, and diabetes, who was not eligible for a kidney transplant and therefore required lifelong dialysis to survive. The renal-dialysis unit in the region where he lived, which had 20 dialysis machines - not nearly enough to provide dialysis for everyone who required it - had a policy of accepting only patients with acute renal failure. The health department argued that this policy met the government's duty to provide emergency care under the constitution. Patients with chronic renal failure, like the petitioner, did not automatically qualify.

In considering whether the constitution required 
the health department to provide a sufficient number of machines to offer dialysis to everyone whose life could be saved by it, the court observed that under the constitution, the state's obligation to provide health care services was qualified by its "available resources." The court noted that offering extremely expensive medical treatments to everyone would make "substantial inroads into the health budget . . . to the prejudice of the other needs which the state has to meet." 12 The Constitutional Court ultimately decided that the administrators of provincial health services, not the courts, should set budgetary priorities and that the courts should not interfere with decisions that are rational and made "in good faith by the political organs and medical authorities whose responsibility it is to deal with such matters." 12

Likewise, in South Africa v. Grootboom, a case involving the right to housing, the Constitutional Court determined that although the state is obligated to act positively to ameliorate the conditions of the homeless, it "is not obligated to go beyond available resources or to realize these rights immediately." 13 The constitutional requirement is that the right to housing be "progressively realized." Nonetheless, the court noted, there is "at the very least, a negative obligation placed upon the state and all other entities and persons to desist from preventing or impairing the right of access to adequate housing."13,14

Applying the rulings in these two cases to the nevirapine case, the Constitutional Court reasonably concluded that the right to health care services "does not give rise to a self-standing and independent fulfillment right" that is enforceable irrespective of available resources. Nonetheless, the government's obligation to respect rights, as articulated in the housing case, applies equally to the right to health care services. ${ }^{9}$

\section{ENFORCING THE OBLIGATION TO PROTECT RIGHTS}

The Constitutional Court reframed the two questions it would answer in the light of the South African government's obligation to take "reasonable steps" for the "progressive realization" of the right to health as follows: "Is the policy of confining the supply of nevirapine reasonable in the circumstances; and does the government have a comprehensive policy for the prevention of mother-to-child transmission of HIV?"9

The South African government argued that the real cost of delivering nevirapine is not the cost of the drug but the cost of the infrastructure of care: HIV testing, counseling, follow-up, and the provision of formula for parents who cannot currently afford it. The Constitutional Court agreed that the ideal is to make these preventive services universally available but restated the dispute as "whether it was reasonable to exclude the use of nevirapine for the treatment of mother-to-child transmission at those public hospitals and clinics where testing and counseling are available." 9

The South African government gave four reasons for its restriction of the use of nevirapine: its efficacy would be diminished in settings in which a comprehensive package of services, including breastmilk substitutes, was not available; administration of the drug might produce a drug-resistant form of HIV; the safety of nevirapine has not been adequately demonstrated; and the public health system does not have the capacity to deliver the "full package" of services. 9

The court addressed each point in turn. With respect to efficacy, the court found that breast-feeding does increase the risk of HIV infection "in some, but not all cases and that nevirapine thus remains to some extent efficacious . . . even if the mother breastfeeds her baby." 9 The court conceded that drug resistance is possible but concluded, "The prospects of the child surviving if infected are so slim and the nature of the suffering [is] so grave that the risk of some resistance manifesting at some time in the future is well worth running." 9 The safety issue was disposed of by reference to the World Health Organization's recommendation of nevirapine and the determination of the Medicines Control Council that the drug is safe. As for capacity, the court concluded that resources are relevant to the universal delivery of the "full package" but are "not relevant to the question of whether nevirapine should be used to reduce mother-to-child transmission of HIV at those public hospitals and clinics outside the research sites where facilities in fact exist for testing and counseling." 9

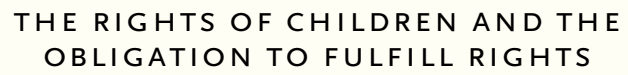

This case is a right-to-health case because it concerns the availability of a drug and the circumstances under which the government can reasonably restrict its use. Nonetheless, the case could have been decided solely on the basis of the rights of children. In the words of the Constitutional Court, "This 
case is concerned with newborn babies whose lives might be saved by the administration of nevirapine to mother and child at the time of birth." 9 The court specifically cites the constitutional rights of children, including their right to "basic health care services." Parents have the primary obligation to provide these services to children but often cannot meet this obligation without help from the state..$^{15}$ The court concluded that nevirapine is an "essential" drug for children whose mothers are infected with HIV, that the needs of these children are "most urgent," and that their ability to exercise all other rights is "most in peril." 9 The court did not write about the certainty of the children becoming orphans if their mothers do not also have access to treatment, but treatment of HIV infection and AIDS was beyond the scope of this case, which concerned the prevention of HIV infection.

On the basis of either the right to health or the rights of children, the court's answer to the first question was that the policy of restricting the availability of nevirapine is unreasonable and a violation of the government's obligation to take "reasonable legislative and other measures, within its available resources, to achieve the progressive realization" of the right to "access to health care services, including reproductive health care." In the court's words, "A potentially lifesaving drug was on offer and where testing and counseling facilities were available it could have been administered within the available resources of the state without any known harm to mother and child." 9 The question of whether the cost of nevirapine mattered was not addressed, although the outcome almost certainly would have been different had nevirapine not been available at no or very low cost.

The answer to the second question - whether the government is required to have a reasonable, comprehensive plan to combat mother-to-child transmission of HIV - flowed directly from the answer to the first. The legal question was whether the government's plan of moving slowly from limited research and training programs to more available programs was reasonable. The court decided that because of the "incomprehensible calamity" of the HIV epidemic in South Africa, the government's plan was not reasonable.

THE RIGHT TO THE PROGRESSIVE REALIZATION OF HEALTH

Can the Constitutional Court be accused of taking on the role of the South African government's health department in deciding how money should be spent on health care? The court did not think so, pointing out that all branches of the government have the obligation to "respect, protect, promote and fulfill" the socioeconomic rights spelled out in the constitution. The legislative branch is obligated to pass "reasonable legislative" measures, and the executive branch is obligated to develop and implement "appropriate, well-directed policies and programs." It is, of course, the role of the judiciary to resolve disputes about whether a specific law or policy, or its implementation, is consistent with the terms of the constitution. Since the initiation of the nevirapine lawsuit, three of the country's nine provinces - Western Cape, Gauteng, and KwaZulu-Natal - have publicly announced a plan to realize progressively "the rights of pregnant women and their newborn babies to have access to nevirapine." 9 The court expects the other six provinces to follow suit.

The court was explicit both in defining the rights that were violated and in ordering a remedy. As to the rights, the court declared that "Sections 27(1) and (2) of the Constitution require the government to devise and implement within its available resources a comprehensive and coordinated program to realize progressively the rights of pregnant women and their newborn children to have access to health services to combat mother-to-child transmission of HIV."9 To implement this right, the court ordered the government to take four specific actions:

Remove the restrictions that prevent nevirapine from being made available . . . at public hospitals and clinics that are not research and training sites.

Permit and facilitate the use of nevirapine . . . at public hospitals and clinics when . . . this is medically indicated. . . .

Make provision if necessary for counselors based at public hospitals and clinics . . . to be trained for counseling. . . .

Take reasonable measures to extend the testing and counseling facilities at hospitals and clinics throughout the public health sector to facilitate and expedite the use of nevirapine. ${ }^{9}$

\section{IMPLEMENTING THE RIGHT TO HEALTH}

The decision in the nevirapine case illustrates both the strength and the weakness of relying on courts 
to determine specific applications of the right to health. The strength is that the right to health is a legal right, and since there can be no legal right without a remedy, courts will provide a remedy for violations of the right to health. In this regard, it is worth noting not only that the right to health and access to health care articulated in the Universal Declaration of Human Rights has been given more specific meaning in the International Covenant on Economic, Social and Cultural Rights ${ }^{10,11}$ and other internationally binding documents on human rights, but also that these rights have been written into the constitutions of many countries, including South Africa. The widespread failure of governments to take the right to health seriously, however, means that we are still a long way from the realization of this right. Nonetheless, the recent activism of many new nongovernmental organizations, such as the Treatment Action Campaign, in the area of health rights, provides some ground for optimism that government inaction will not go unchallenged. ${ }^{16}$

The weakness of relying on courts is that the subject matter of the right to health in a courtroom struggle is likely to be narrow, involving interventions such as kidney dialysis or nevirapine therapy. The HIV epidemic demands a comprehensive strategy of treatment, care, and prevention, including education, adequate nutrition, clean water, and nondiscrimination. 2,11,17 The government of South Africa has so far been unwilling to designate the HIV epidemic as a national emergency or to take steps to make the prevention and treatment of HIV infection its highest health priority. This stance has apparently changed little since the decision on nevirapine was handed down. The South African government, for example, has asked the Medicines Control Council to review its approval of nevirapine because of continued doubt about its safety and efficacy. ${ }^{18}$ Of course, if the council withdraws its approval of the drug, this action will effectively render the Constitutional Court's decision moot, since its orders are based on the finding that nevirapine is safe and effective. On the more positive side, South Africa's cabinet has announced that it is considering universal access to antiretroviral drugs, and Ranbaxy, the largest manufacturer of generic drugs in India, has formed a jointventure with Adcock Ingram to distribute generic antiretroviral agents in South Africa. ${ }^{19}$

Former South African president Nelson Mandela has persuasively argued that an effective strat- egy for combatting the AIDS epidemic requires the engaged commitment of national leaders to provide not only prevention but also treatment for everyone who needs it, "wherever they may be in the world and regardless of whether they can afford to pay or not." ${ }^{20}$ Lack of leadership in addressing the HIV epidemic specifically and the right to health in general is not, of course, confined to South Africa.

From the Health Law Department, Boston University School of Public Health, Boston.

1. McGreal C. The shame of the new South Africa. The Guardian (London). November 1, 2002:2.

2. Mann JM. Human rights and AIDS: the future of the pandemic. In: Mann JM, Gruskin S, Grodin MA, Annas GJ, eds. Health and human rights: a reader. New York: Routledge, 1999:216-26.

3. Farmer P. The major infectious diseases in the world - to treat or not to treat? N Engl J Med 2001;345:208-10.

4. Makgoba MW. HIV/AIDS: the peril of pseudoscience. Science 2000;288:1171.

5. Swarns RL. An AIDS skeptic in South Africa feeds simmering doubts. New York Times. March 31, 2002(section 1):4.

6. Barnard D. In the high court of South Africa, case no. 4138/98: the global politics of access to low-cost AIDS drugs in poor countries. Kennedy Inst Ethics J 2002;12:159-74.

7. Guay LA, Musoke P, Fleming T, et al. Intrapartum and neonatal single-dose nevirapine compared with zidovudine for prevention of mother-to-child transmission of HIV-1 in Kampala, Uganda: HIVNET 012 randomised trial. Lancet 1999;354:795-802.

8. Treatment Action Campaign v. Minister of Health, High Court of South Africa, Transvaal Provincial Div., 2002 (4) BCLR 356(T), Dec. 12, 2001.

9. Minister of Health v. Treatment Action Committee, Constitutional Court of South Africa, 2002 (10) BCLR 1033.

10. Steiner HJ, Alston $P$, eds. International human rights in context: law, politics, morals. 2nd ed. New York: Oxford University Press, 2000:1395-401.

11. United Nations, Economic and Social Council, Committee on Economic, Social and Cultural Rights. General comment no. 14: the right to the highest attainable standard of health. New York: United Nations, 2000.

12. Soobramoney v. Minister of Health (KwaZulu-Natal), Constitutional Court of South Africa, 1997 (12) BCLR 1696.

13. South Africa v. Grootboom, Constitutional Court of South Africa, 2000 (11) BCLR 1169.

14. Tarantola D, Gruskin S. Children confronting HIV/AIDS: charting the confluence of rights and health. Health Hum Rights 1998;3: 60-86.

15. Ngwena C. The recognition of access to health care as a human right in South Africa: is it enough? Health Hum Rights 2000;5:26-44.

16. Torres MA. The human right to health, national courts, and access to HIV/AIDS treatment: a case study from Venezuela. Chic J Int Law 2002;3:105-15.

17. De Cock KM, Mbori-Ngacha D, Marum E. Shadow on the continent: public health and HIV/AIDS in Africa in the 21st century. Lancet 2002;360:67-72

18. Baleta A. S Africa soaks up pressure to change HIV/AIDS policy. Lancet 2002;360:467.

19. Innocenti NG. Ranbaxy in link on AIDS drugs for Africa. Financial Times (London). October 18, 2002:29.

20. Mandela N. Care support and destigmatization. Plenary address presented at the XIV International AIDS Conference, Barcelona, Spain, July 7-12, 2002.

Copyright (C) 2003 Massachusetts Medical Society. 